\title{
Revision of the genus Callipteroma Motschulsky, 1863 (Hymenoptera: Encyrtidae)
}

\author{
Ревизия рода Callipteroma Motschulsky, 1863 \\ (Hymenoptera: Encyrtidae)
}

\author{
V.A. Trjapitzin ${ }^{1}$, S.V. Triapitsyn ${ }^{2}$ \\ B.A. Тряпиџын ${ }^{1}$, С.В. Тряпиџын ${ }^{2}$
}

\footnotetext{
${ }^{1}$ Do vostrebovania, Post Office 129344 (ulitsa letchika Babushkina, 7), Moscow, Russia.

2 Department of Entomology, University of California, Riverside, California, 92521, USA.

1 До востребования, п/о 129344 (ул. лётчика Бабушкина, д. 7), Москва, Россия.
}

KEY WORDS: Hymenoptera, Encyrtidae, Callipteroma, Eastern Hemisphere, taxonomy, key, new synonymy.

КЛЮЧЕВЫЕ СЛОВА: Hуmenoptera, Encyrtidae, Callipteroma, Восточное полушарие, таксономия, определительная таблица, новые синонимы.

ABSTRACT: A diagnosis of the genus Callipteroma Motschulsky, 1863 (Hymenoptera: Encyrtidae), a key to females of its six known species, and their synopsis are given based on examination of the type material of four of them. Taxonomic position of Callipteroma is discussed. Proleptomastidea Trjapitzin, 2009 syn.n. is synonymized under Callipteroma and its sole species, P. enigmatica (Trjapitzin, 1971), is transferred to Callipteroma as $C$. enigmatica (Trjapitzin, 1971) comb.n. Callipteroma baglanensis Myartseva, 1982 stat.rev. from Afghanistan is treated, albeit provisionally, as not being a synonym of $C$. testacea Motschulsky, 1863. Leptomastix calopterus Masi, 1921, syn.n. from Libya is synonymized under $C$. sexguttata Motschulsky, 1863. Lectotypes of the three species of Callipteroma described by Motschulsky from Sri Lanka, C. quinqueguttata Motschulsky, 1863 (a synonym of $C$. sexguttata), $C$. sexguttata, and $C$. testacea, and also of Encyrtus nietneri Motschulsky, 1859 (now Microterys nietneri (Motschulsky, 1859)) are designated. Only one species of Callipteroma, C. sexguttata, is known to occur in Russia.

РЕЗЮМЕ: В статье приводятся диагноз рода Callipteroma Motschulsky, 1863 (Hymenoptera: Encyrtidae), определительная таблица шести его известных видов, а также дан их обзор на основе исследования типового материала четырёх из них. Обсуждается таксономическое положение Callipteroma. Proleptomastidea Trjapitzin, 2009 syn.n. сведён в синонимы к Callipteroma и его единственный вид, P. enigmatica (Trjapitzin, 1971), переведён в Callipteroma как C. enigmatica (Trjapitzin, 1971) comb.n. Callipteroma baglanensis Myartseva, 1982 stat.rev. из Афганистана трактуется предварительно не как синоним C. testacea Motschulsky, 1863. Leptomastix calopterus Masi, 1921, syn.n. из Ливии сведён в синонимы к C. sexguttata Motschulsky, 1863. Выделены и обозначены лектотипы трёх видов Callipteroma описанных Мочульским из Шри-Ланки: C. quinqueguttata Motschulsky, 1863 (синоним $C$. sexguttata), C. sexguttata и C. testacea, а также Encyrtus nietneri Motschulsky, 1859 (теперь Microterys nietneri (Motschulsky, 1859)). Только один вид Callipteroma, C. sexguttata, известен из России.

\section{Introduction}

Only six species of Callipteroma Motschulsky, 1863 (Hymenoptera: Encyrtidae) are currently recognized. Three nominal species of this genus were described [Motschulsky, 1863] from Ceylon (now Sri Lanka) by the famous Russian entomologist Victor Ivanovich Motschulsky (1810-1871), whose memoirs were published by Krivokhatsky and Mikhailov [2013]. During the last 50 years, the senior author has examined the types of Encyrtidae described by Motschulsky; these are deposited in the collection of Zoological Museum of M.V. Lomonosov Moscow State University, Moscow, Russia. Among them redescriptions of the following species were published to this date: Diversinervus paradisicus (Motschulsky, 1863) [Trjapitzin, 1961], Charitopus cuprifrons (Motschulsky, 1863) [Trjapitzin, 2008], and Microterys nietneri (Motschulsky, 1859) [Trjapitzin et al., 2008]. Redescription of Callipteroma testacea Mots-

How to cite this article: Trjapitzin V.A., Triapitsyn S.V. 2018. Revision of the genus Callipteroma Motschulsky, 1863 (Hymenoptera: Encyrtidae) // Russian Entomol. J. Vol.27. No.2. P.191-198. doi: 10.15298/rusentj.27.2.09 
chulsky, 1863, collected by Y.S. Darevsky in "Tomodo and Padar Islands (Indonesia), was prepared in comparison with the male syntype of this species [Trjapitzin, 1965].

Acronyms of the depositories of the specimens are as follows: BMNH - The Natural History Museum, London, England, UK; HNHM - Hungarian Natural History Museum, Budapest, Hungary; IBCM - Institute of Genetics, Physiology and Plant Protection (formerly Institute of Plant Protection and Ecological Agriculture), Academy of Sciences of Moldova, Kishinev (Chisinau), Moldova; MNCN - Museo Nacional de Ciencias Naturales, Madrid, Spain; SIZK - I.I. Schmalhausen Institute of Zoology, National Academy of Sciences of Ukraine, Kiev, Ukraine; UCRC Entomology Research Museum, University of California, Riverside, California, USA; ZISP — Zoological Institute, Russian Academy of Sciences, Saint Petersburg, Russia; ZMHB - Museum für Naturkunde, Humboldt-Universität, Berlin, Germany; ZMMU Zoological Museum of M.V. Lomonosov Moscow State University, Moscow, Russia.

Using this opportunity, here we also designate a lectotype [ZMMU] of Encyrtus nietneri Motschulsky, 1859 (now Microterys nietneri (Motschulsky, 1859)) to avoid any ambiguity about the type material of this subtropical and tropical species, an effective parasitoid of Coccidae (Hemiptera), and its identity because Motschulsky [1859] did not mention any specimens in its original description; Trjapitzin et al. [2008] studied the syntypes of this taxon from Sri Lanka but did not designate a lectotype. The syntypes of Encyrtus nietneri ( 6 females, ZMMU) are mounted on two pins, as follows. The first pin (with 5 females on a paper triangle) is labeled (from above): 1 . [a small red quadrate]; 2. [a small yellow circle]; 3. [rectangle] "Type"; 4. [a white original label either of Motschulsky or Nietner] "Parasit auf Pseudococcus coffeae"; 5. [a big yellow label in handwriting of Motschulsky] "Encyrtus Nietneri Motsch. Ceylon" [then illegible]; 6. [a red label written by V.A. Trjapitzin] "Lectotypus and paralectotypi, 00 , Encyrtus nietneri Motschulsky. Lectotypus: foremost specimen, design. Sugonjaev et Trjapitzin" [this designation was never published]; 7. [white] "Micr. Slides [in Russian] N2681 (Lectotypus), 2682 (Paralectotypus)" [these slides were prepared by E.S. Sugonjaev and are deposited in ZISP]; 8. [in handwriting of V.A. Trjapitzin] "Microterys nietneri. Det. V.A. Trjapitzin, 2008". The lectotype designated here is the same specimen as indicated as such on the labels (but not previously published); the other specimens are paralectotypes. The second pin (with 1 female paralectotype) is labeled as follows: 1 . a yellow circlet; 2. 6. [a red label written by V.A. Trjapitzin] "Paralectotypus. Encyrtus nietneri Motschulsky, + Design. Sugonjaev et Trjapitzin" [this designation was never published]; 3. [red] "Microterys nietneri (Motschulsky), +"; 4. [white] "Microterys nietneri (Motschulsky), ․ Det. V.A. Trjapitzin”.
Genus Callipteroma Motschulsky, 1863

Callipteroma Motschulsky, 1863: 35.

Type species: Callipteroma sexguttata Motschulsky, 1863, by subsequent designation [Ashmead, 1900: 402 (as Callipteroma quinqueguttata Motschulsky, 1863)].

Calliopteroma Dalla Torre, 1898: 307 (invalid emendation).

Calocerinella Girault, 1913: 46-47.

Type species: Calocerinella trifasciatus [correct spelling: trifaciata] Girault, 1913, by monotypy. Synonymy by Noyes, 1978: 539. Callipteroma: García Mercet, 1921: 56, 115-116; Gahan, Fagan, 1923: 26; Noyes, 1978: 539-540; Noyes, Hayat, 1984: 244; Kaul, Agarwal, 1986: 53-55; Mani, 1989: 813-814; Trjapitzin, 1989: 44, 145-147; Noyes, Hayat, 1994: 250-252; Hayat, 2006: 264.

Proleptomastidea Trjapitzin, 2009: 165, 176, syn.n.

Type species: Leptanusia enigmatica Trjapitzin, 1971b, by original designation and monotypy.

DIAGNOSIS. Female. Body compact, not flattened, without metallic luster. Frontovertex very broad. Scrobes either connected or separated above. Toruli above lower eye margin level. Scape not broadened, long; funicle 6-segmented, with all segments longer than wide; clava 3-segmented, short, not truncate at apex, sutures dividing claval segments transverse. Mandible with 2 acute teeth. Palpal formula in C. sexguttata 4-3. Pronotum short. Mesoscutum without notauli. Scutellum triangular. Wings not abbreviated; fore wing long, strongly darkened (brown) and with light spots (Figs 1, 5-6) or with alternating hyaline transverse or oblique (Figs 3-4, 7-8) fasciae; costal cell almost absent or very narrow; marginal vein somewhat longer than wide; stigmal vein with uncus; postmarginal vein rather well developed. Legs long and thin; mesotibial spur long. Propodeum, except its longitudinally depressed median part, with light pubescence. Gaster short: $1^{\text {st }}$ gastral ( $=3^{\text {rd }}$ abdominal) tergite either rounded posteriorly (e.g., in the type species, Fig. 1) or with a large triangular projection in the middle (Fig. 7); pygostyles near base of gaster. Hypopygium extending to apex of gaster. Ovipositor not exserted. Body length 1.3-2.5 mm.

Male. Funicle segments long, with long setae; clava entire. Pattern on fore wing disc similar to that of female.

REMARKS. It remains to be demonstrated whether inclusion in the same genus (Callipteroma) of the species with the $1^{\text {st }}$ gastral tergite either rounded posteriorly or with a large triangular projection in the middle is justified.

DISTRIBUTION. Species of Callipteroma are more or less common in the tropical and subtropical Regions of the Old World; in the Palearctic Region they occur predominantly in steppes, semideserts, and in other arid habitats. The most northern finds of the genus are from Slovakia, Moldova and Orenburgskaya Oblast' of Russia.BIOLOGY. Without any doubt, most Callipteroma species are primary endoparasitoids of mealybugs (Hemiptera: Pseudococcidae), as are most Tetracneminae, but the tentatively included $C$. enigmatica was reared from Eriococcidae (Hemiptera) [Myartseva, 1978].

SYSTEMATIC POSITION. Motschulsky [1863] placed Callipteroma in the family Braconidae. Ashmead [1900] transferred it to the subfamily Encyrtinae, then within the family Chalcididae (which now corresponds to the superfamily Chalcidoidea). Trjapitzin [1968] established the subtribe Leptomastideii (now Leptomastideina Trjapitzin, 1968) in the tribe Anagyrini Hoffer, 1953 of the subfamily Tetracneminae. This subtribe was defined based on the position of the wing of the active, live adults holding them erect (vertically or aslantly). Its members then included, besides Callipteroma, the genera Leptomastidea García Mercet, 1916 and Leptanusia De Santis, 1964 [Trjapitzin, 1968], but the latter is now considered to be a synonym of another closely related genus, Gyranusoidea Compere, 1947 [Noyes, 1980]. 
Recently, Trjapitzin [2009] added Proleptomastidea Trjapitzin, 2009 as another member of this subtribe, with Leptanusia enigmatica Trjapitzin, 1971 as type species of the genus. Because it is not clear (and mostly unknown) if live adults of most species comprising Gyranusoidea hold their wings erect, at an angle, or fold them (possibly, some do and some do not), and the genus itself is extremely difficult to separate morphologically from Anagyrus Howard 1896 and Leptomastidea [Triapitsyn et al., 2014], the current, rather ambiguous, subtribal arrangement within the Anagyrini would need to be re-assessed based on a thorough phylogenetic study using evidence from both morphological and molecular data, which are now lacking. It is quite unlikely that such closely related and similar, rather poorly defined genera would belong to different subtribes within the Anagyrini. According to personal observations of the junior author of this communication, live adults of Gyranusoidea indica Shafee, Alam \& Agarwal, 1975 hold their wings at a $30^{\circ}$ to $40^{\circ}$ angle to the body axis (Fig. 10), whereas those of Leptomastidea abnormis (Girault, 1915) and Leptomastidea sp. from Puerto Rico [Triapitsyn et al., 2014] hold them erect, almost perpendicular to the body; on the other hand, live adults of Anagyrus kamali Moursi, 1948 fold their wings and hold them parallel to the body axis.

Proleptomastidea was very briefly, rather poorly defined and separated from Leptomastidea based on a larger body size, the palpal formula of $4-3$, and a shorter postmarginal vein of the fore wing. These features are of a doubtful generic value and two of them were vaguely indicated, except for the palpal formula, which is the same as in the only known such formula in $C$. sexguttata. However, palpal formula is known to vary a lot in some other, unrelated genera of Encyrtidae and is often size-dependent: the larger species having more palpal segments than smaller ones within the same genus. Therefore, we hereby synonymize, with some reservations, Proleptomastidea under Callipteroma because the former nominal genus more or less fits the above diagnosis of the latter, which is the oldest described taxon in this unstable and difficult to figure out group and thus would preserve its name even in the likely scenario that Leptomastidea may eventually be recognized as a junior synonym of Callipteroma, whether completely or partially, or in combination with at least some species of Gyranusoidea. Such a generic revision, preferably of the entire Anagyrini, is well beyond the scope of this communication, and would require a detailed study of several key morphological structures, particularly of gaster.

Vosleria Timberlake, 1926, which had been treated as a synonym of Callipteroma by Noyes and Hayat [1984] but later was resurrected by them as a valid genus [Noyes, Hayat, 1994], is also in or near that mix of rather fuzzily delimited genera that was called by Noyes and Hayat [1994] the Leptomastix Foerster, 1856 lineage within the Anagyrini. The junior author examined and identified the following specimens of the only described member of Vosleria, V. australia (Girault, 1917): AUSTRALIA: New South Wales, Sydney, 1931, S. Flanders, "Ex. Mealy bug on grass roots" [1 female, UCRC] (determined by H. Compere as Vosleria signata Timberlake, 1926); Queensland: Brisbane, Acacia Ridge, 15.ix.1980, G. Gordh [1 female, UCRC] (Fig. 9); Calam Rd., 31.viii.1980, G. Gordh, E. Dahms [1 female, UCRC]; Browns Plains, 13.ix.1980, G. Gordh, E. Dahms [1 female, UCRC]; Cape Hillsborough National Park, 15.x.1979, H. E. Evans [1 female, UCRC]; Gatton, 11.ix.1980, G. Gordh, E. Dahms [1 female, UCRC]. Also, there are many males with hyaline fore wings in the UCRC that were determined by J. S. Noyes in 1998 as ?Vosleria sp.; many of these were collected in

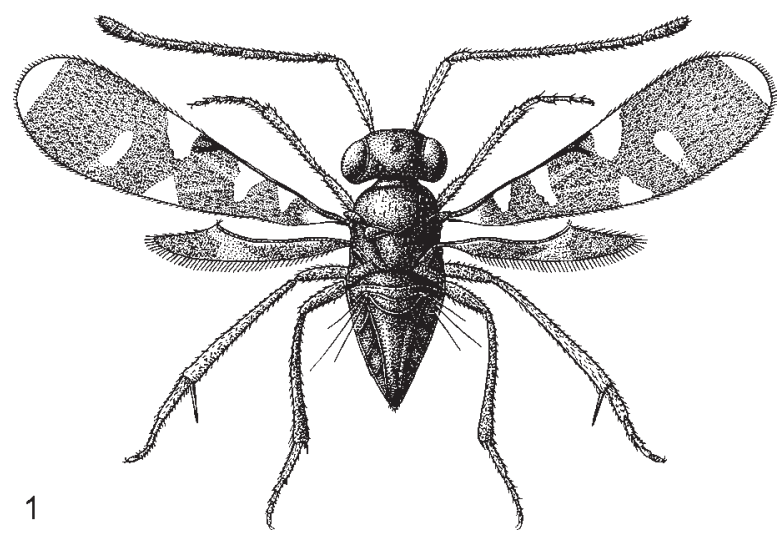

Fig. 1. Callipteroma sexguttata, female habitus (drawing by E.K. Herthevtzian)

Рис. 1. Callipteroma sexguttata, габитус самки (рисунок Е.К. Эртевцян).

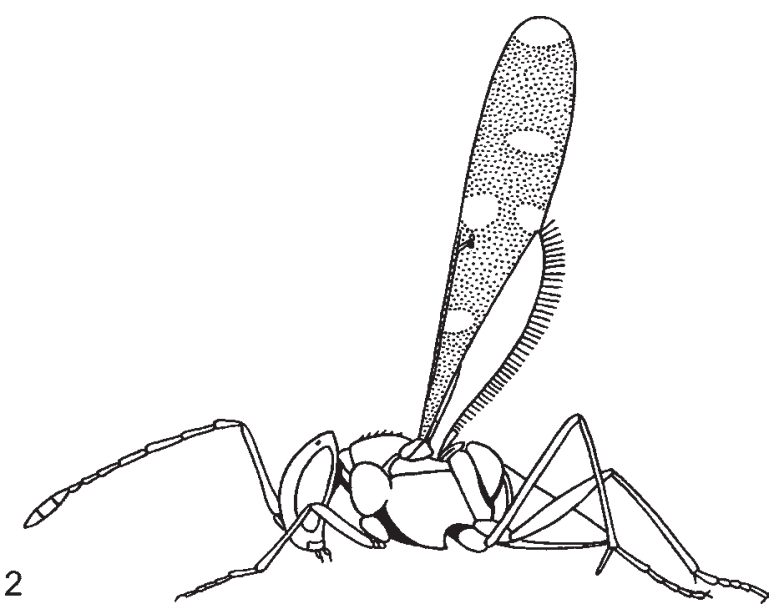

Fig. 2. Callipteroma sexguttata, female habitus [from García Mercet, 1921].

Рис. 2. Callipteroma sexguttata, габитус самки [по García Mercet, 1921].

Queensland, Australia in the same localities and about at the same time as the females of $V$. australia listed above (determined by J. S. Noyes in 1998 as Vosleria sp.), so they very well could be conspecific with them.

Callipteroma enigmatica (Trjapitzin, 1971) comb.n. (Fig. 4) holds its wings erect (personal observation of the first author [Trjapitzin, 1971b]) as do other members of this genus.

\section{Key to SPECIES OF CALLIPTEROMA (FEMALES)}

1(2) Clava with two apical segments yellowish-white. Length of body $1.7 \mathrm{~mm}$. 1. C. albiclava

2(1) Clava unicolorous, dark.

3(6) Posterior margin of $1^{\text {st }}$ gastral tergite not triangular, rounded (Figs 1, 4).

4(5) Fore wing beyond venation mostly dark brown, with 4 small hyaline spots (Fig. 1). Length of body 1.3-2.5 mm 5. C. sexguttata

5(4) Fore wing beyond venation with 1 brown transverse band and 2 hyaline transverse bands (Fig. 4). Length of body $1.5-2.0 \mathrm{~mm}$ 3. C. enigmatica 6(3) Posterior margin of $1^{\text {st }}$ gastral tergite triangular (Fig. 3). 
7(8) Basal edge of $3^{\text {rd }}$ dark fascia on fore wing without a triangular projection. Length of body $1.7 \mathrm{~mm}$.

4. C. nigra

8(7) Basal edge of $3^{\text {rd }}$ dark fascia on fore wing with a triangular projection (Fig. 3).

9(10) Propodeum in the middle with a thin longitudinal keel. Length of body $2.2 \mathrm{~mm}$.................... 2. C. baglanensis 10(9) Propodeum in the middle without keel. Length of body $2.2 \mathrm{~mm}$ 6. C. testacea

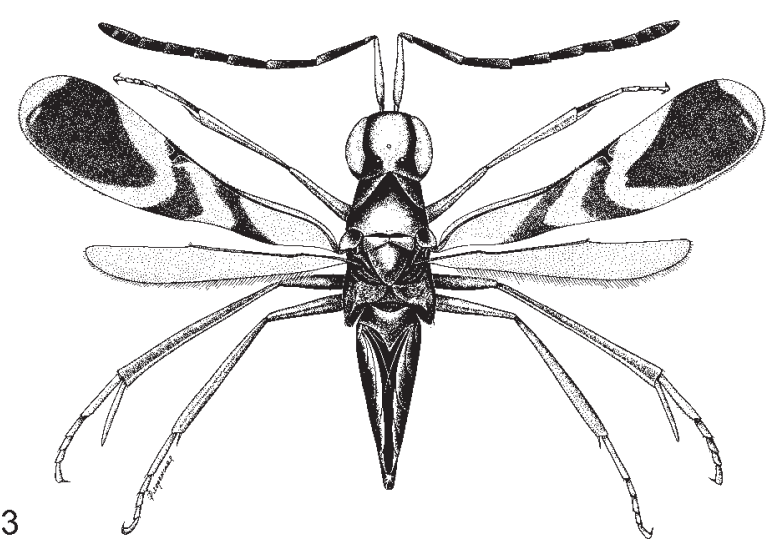

Fig. 3. Callipteroma baglanensis, female habitus, holotype (drawing by N.A. Florenskaya).

Рис. 3. Callipteroma baglanensis, габитус самки, голотип (рисунок Н.А. Флоренской).

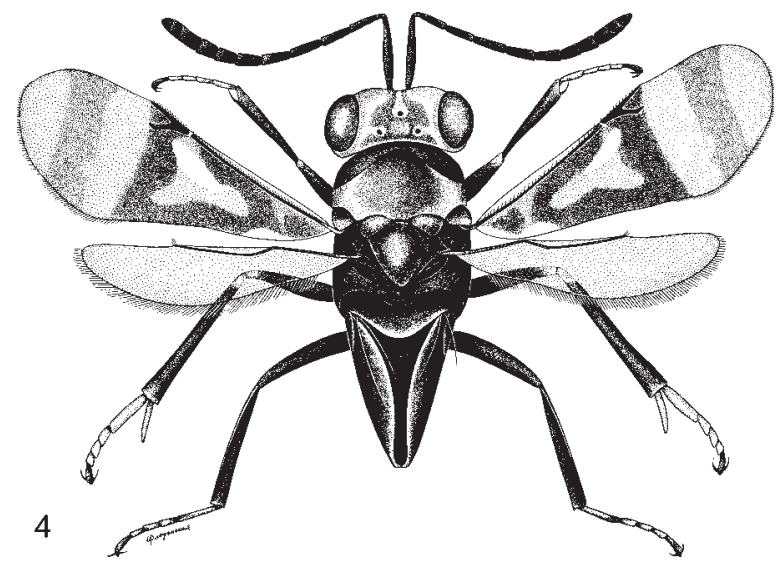

Fig. 4. Callipteroma enigmatica, female habitus (drawing by N.A. Florenskaya).

Рис. 4. Callipteroma enigmatica, габитус самки (рисунок Н.А. Флоренской).
Alphabetical synopsis of species

1. Callipteroma albiclava Noyes, 1978

Noyes, 1978: 541-543.DISTRIBUTION. Republic of South Africa.

HOSTS. Unknown.

\section{Callipteroma baglanensis Myartseva, 1982,} stat.rev.

Fig. 3.

Trjapitzin, 1971a: 77 (Callipteroma sp.); Myartseva, 1982: $45-$ 46 (C. baglanense); Trjapitzin, 1989: 147; Noyes, Hayat, 1994: 257 (possibly a synonym of $C$. testacea Motschulsky, 1863); Japoshvili, Noyes, 2005: 137 (as C. testacea).

DISTRIBUTION. Afghanistan.

HOSTS. Unknown.

TYPE MATERIAL EXAMINED. Holotype (Fig. 3) female [ZISP] on point: Baglan, North Afghanistan, sandy plot of floodlands with sparse gramineous plants, and also with tamarisk and sugarcane, 7.ix.1966 (E.S. Sugonjaev) [label in Russian]. Also some body parts on slide No. 1649 .

REMARKS. According to Noyes and Hayat [1994], $C$. baglanensis may be synonymous with $C$. testacea because both nominal species have an elongate and flat propodeum, and their pattern of infuscation of the fore wing is somewhat similar (although not matching), also considering some variability of that in C. testacea. Later, Japoshvili and Noyes [2005] formally synonymized the former under the latter. Their nomenclatural action deserves attention, but for now we cannot accept it because there is a difference between them in the structure of the propodeum (see the key). Unfortunately, on the habitus drawing of the holotype female of C. baglanensis (Fig. 3) a thin longitudinal keel on the propodeum, characteristic of this species, is not shown. More material of this species (now non-existent) is needed to be examined to better assess its validity.

\section{Callipteroma enigmatica (Trjapitzin, 1971), comb.n.}

Fig. 4.

Trjapitzin, 1971b: 86-89 (Leptanusia); Hoffer, 1975: 112-112 (Leptanusia); Myartseva, 1978: 163-164 (Leptanusia); 1984: 116, 203 (Leptanusia); 1986: 217 (Leptanusia); Trjapitzin, 1989: 143 (Leptomastidea); 2009: 203-204 (Proleptomastidea).

DISTRIBUTION. Algeria and Turkmenistan.

HOST. Neoacanthococcus tamaricicola Borchsenius, 1948 (Eriococcidae) on Tamarix sp. [Myartseva, 1978].

\section{Callipteroma nigra García Mercet, 1924}

García Mercet, 1924: 258-260; Nikol'skaya, 1952: 346; 1963:

353; Noyes, 1978: 541, 545-546; Trjapitzin, 1989: 147.

DISTRIBUTION. Spain.

HOSTS. Unknown.

TYPE MATERIAL EXAMINED. Holotype female [MNCN]: Rivas-Vaciamadrid, Madrid, Spain.

\section{Callipteroma sexguttata Motschulsky, 1863 Figs 1-2, 5-6.}

Callipteroma quinqueguttata Motschulsky, 1863, synonymy by Bouèek, 1977: 70; Leptomastix guttatipennis Girault, 1915, synonymy under C. quinqueguttata by Noyes, 1978: 546; Leptomastix guttatipennis io Girault, 1919, synonymy under C. quinque-

Рис. 5-10. Callipteroma spp.: 5-6, 8 - C. sexguttata (5 - Исследовательский центр Мпала, графство Лаикипия, Кения; 6 Фальшивый Геленджик, Краснодарский край, Россия; 8 - Акация Ридж, Брисбен, Квинсленд, Австралия); 7 - C. testacea (Гаттон, Квинсленд, Австралия; стрелки указывают на 1-й тергит гастера, в т.ч. на вставке); 9 - Vosleria australia (Акация Ридж, Брисбен, Квинсленд, Австралия); 10 - Gyranusoidea indica (из колонии в карантинной лаборатории Калифорнийского университета в Риверсайде); 5, 7, 9 - габитус самки; 6, 8 - габитус самца; 10 - взрослые особи. 


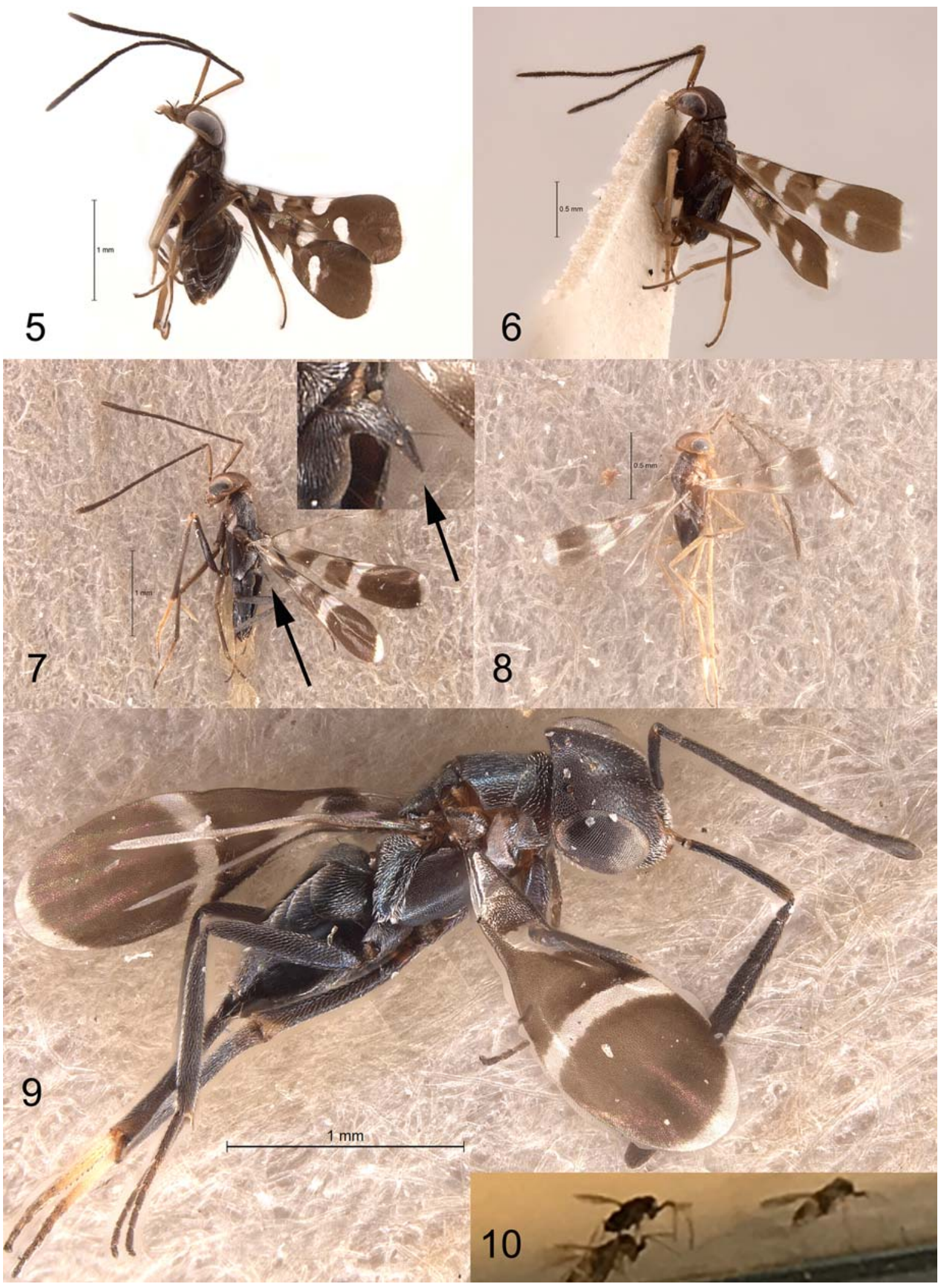

Figs 5-10. Callipteroma spp.: 5-6, 8-C. sexguttata (5 - Mpala Research Centre, Laikipia County, Kenya; 6 - Fal'shivyy Gelendzhik, Krasnodarskiy Kray, Russia; Acacia Ridge, Brisbane, Queensland, Australia); 7 - C. testacea (Gatton, Queensland, Australia; arrows point to $1^{\text {st }}$ gastral tergite, including on the insert); 9 - Vosleria australia (Acacia Ridge, Brisbane, Queensland, Australia); 10 - Gyranusoidea indica (from colony in University of California at Riverside quarantine laboratory); 5, 7, 9 - female habitus; 6,8 - male habitus; $10-$ live adults. 
guttata by Noyes, 1978: 546; Leptomastix calopterus Masi, 1921 syn.n.; Callipteroma kiushiuensis Ishii, 1928, synonymy under $C$. quinqueguttata by Tachikawa, 1962: 79 .

Motschulsky, 1863: 36-37 (C. quinqueguttata), 37 (C. sexguttata); Girault, 1915: 151 (Leptomastix guttatipennis); 1919: 165 (Leptomastix guttatipennis io); Masi, 1921: 301-303 (Leptomastix calopterus); García Mercet, 1921: 116-119, 688; Ishii, 1928: 9698 (C. kiushiuensis); Nikol'skaya, 1952: 346; 1963: 353; Tachikawa, 1963: 53-54 (C. quinqueguttatum); Erdős, 1964: 56-57; Mani, Kaul, 1974: 67-71 (C. sexguttata); 71-72 (C. quinqueguttata) Hayat, 1974: 407-408 (C. quinqueguttata); Noyes, 1978: 546-548 (C. quinqueguttata); Trjapitzin, 1978: 277 (C. sexguttatum); Myartseva, 1984: 118, 205 (C. sexguttatum); Kaul, Agarwal, 1986: 55-57 (C. quinqueguttatum); Herthevtzian, 1986: 31 (C. sexguttatum); Mani, 1989: 814 (C. quinqueguttata); Trjapitzin, 1989: 146-147 (C. quinqueguttata); Noyes, Hayat, 1994: 252-255; Hayat, 2006 : 264-265.

DISTRIBUTION. Portugal, Spain, Slovakia, Hungary, Croatia, Montenegro, Romania, Bulgaria, Greece, Russia (Crimea, Krasnodarskiy Kray, Orenburgskaya Oblast'), Ukraine (Odesskaya Oblast'), Moldova, Turkey, Israel, Saudi Arabia, Libya, Georgia, Armenia, Azerbaijan, Kazakhstan, Turkmenistan, Mongolia, China, Japan, Pakistan, India, Bangladesh, Sri Lanka, Thailand, Malaysia, Singapore, Indonesia, Papua New Guinea, Australia, Gambia, Burkina Faso, Ghana, Nigeria, Cameroon, Ethiopia, Uganda, Kenya [new record], Malawi, Zambia, Zimbabwe, Republic of South Africa, Madagascar.

HOSTS. Birendracoccus saccharifolii (Green, 1908) (Pseudococcidae) on sugarcane in India [Noyes, Hayat, 1994], Heliococcus summervillei Brookes, 1978, on Paspalum dilatatum in Australia [Summerville, 1928], and unidentified Pseudococcidae on Cocculus trilobus in Japan [Tachikawa, 1970].

TYPE MATERIAL EXAMINED. 2 male syntypes of $C$. sexgut tata [ZMMU] on one paper rectangle labeled: 1. "des somite du mont Patannas" [on summit of Mount Patannas]; 2. [a small yellow circle]; 3. [a small rectangle] "type"; 4. [a yellow label of Motschulsky] "Callipteroma sexguttata Motsch. I. de Ceyl. M' Pat."; 5. [a red label of V. A. Trjapitzin] "Callipteroma sexguttata Motschulsky, $\sigma^{7} \sigma^{7}$. Syntypi”; 6. [red] "Callipteroma sexguttata Motschulsky, lectotypus $\bigcirc^{7}$ [with undamaged right antenna], des. V. A. Trjapitzin"; 7. "Callipteroma sexguttata Motschulsky, $\sigma^{7} \sigma^{7}$, det. V. A. Trjapitzin, 2008". The lectotype, here designated to avoid any confusion about the type specimens of this species and its identity, is the male with one undamaged antenna; the other male (the paralectotype) has undamaged wings.

4 female syntypes of $C$. quinqueguttata [ZMMU] on one paper triangle, in a very bad condition (strongly damaged), labeled: 1 . [a small yellow circle]; 2. [a small rectangle] "type"; 3. [a yellow label of Motschulsky in his handwriting] "Callipteroma quinqueguttata Motsch."; 4. [a red label of V. A. Trjapitzin] "Callipteroma sexguttatum Motschulsky, +. Syntypi. I. of Ceyl. M' Pat.”; 5. [a red label of V. A. Trjapitzin] "LECTOTYPUS $q$ with undamaged wings and antennae (except apical parts)"; 6. [white] "Callipteroma sexguttata Motschulsky, OO, det. V. A. Trjapitzin, 2008"; 7. [red] "Callipteroma quinqueguttata Motschulsky, . . Paralectotypus, des. V. A. Trjapitzin"; 8. [white] "Callipteroma sexguttata Motschulsky, , det. V. A. Trjapitzin, 2008". The lectotype, here designated to avoid any confusion about the type specimens of this species and its identity, is the female with undamaged wings and antennae (except for their apical parts); the other females are paralectotypes.

MATERIAL EXAMINED. RUSSIA: Crimea: Karabi-Yayla, in karst craters, 3.ix.1963, V. Tanasijtshuk [1 female, ZISP]; Nikita [Botanical] Garden [1 female, SIZK]. Krasnodarskiy Kray, Fal'shivyy Gelendzhik, on grasses at seaside (limestone), 30.viii.1963, E. S. Sugonjaev [1 female, 1 male, UCRC]; Orenburgskaya Oblast', Verkhne-Dneprovka, 18.viii.1934, L. Zimin [1 female, ZISP] (determined by V. V. Gussakovsky); MOLDOVA: Kotovskoye [1 female, IBCM]; TURKEY: Mugla: Flos, 500-70 m, 27.viii.1992, J. S. Noyes [1 male, BMNH]. Fetiye, Ole Deniz, 300 m, 3.viii.1992, J.
S. Noyes [1 female, BMNH]; ISRAEL: Kirjat Anawim, 3.vi.1931, S. Bodenheimer [1 male, ZMHB]; Kubeleh (near Jerusalem), 600 m, 16.vi.1958, Y. Klapperich [1 female, HNHM]; GEORGIA: Adjara, Keda, pine forest and its edge, 3.vii.1953, V.A. Trjapitzin [1 female, ZISP]; AZERBAIJAN: Nakhchivan Autonomous Republic, Dzhulfa, arsenic works, 30.v.1957, V. A. Trjapitzin [1 male, ZISP]; KAZAKHSTAN: Akmola Region, Korshetau Mountains, BoagaUzek River valley, sweeping gramineous grasses in steppe, 27.v.1957, V. I. Tobias [1 female, ZISP]; Karaganda Region, $40 \mathrm{~km} \mathrm{~S}$ of ZhanaArka, among Agropyrum desertorum, 15.ix.1960, A. F. Emeljanov [1 female, ZISP]; MONGOLIA: $15 \mathrm{~km} \mathrm{WNW} \mathrm{of} \mathrm{Dzakhol,} \mathrm{on}$ Nitraria sp., 24-26.1970, E. P. Nartshuk [2 females, ZISP]; CHINA: Macao (Macau), xii.1906, F. Muir [1 female, UCRC]; JAPAN: Shikoku Island, Ehime Prefecture, Matsuyama, 3.v.1954 and 18.ix.1960 [2 females, ZISP] (identified by T. Tachikawa as $C$. kiushiuensis Ishii, 1928); INDIA: Delhi, New Delhi, Indian Agricultural Research Institute, 300 m, 8.vii.1990, J. M. Heraty [1 male, UCRC] (determined by M. Hayat); ETHIOPIA: Ambo, savannah: 17.ii.1980, V. Matsyuk [1 male, ZISP]; 14.v.1985, V. I. Pilipyuk [1 female, ZISP]; Guder, Dgafields, 17.vi.1985, V. I. Pilipyuk [1 male, ZISP]; UGANDA: Katona, ix.1913, Mujenje [1 female, MNCN]; KENYA: Kakamega County, Isecheno Nature Reserve, $0^{\circ} 14 ' 24$ '’ $\mathrm{N}$ 3452'12''E, 1617 m, 8.ix.2000, R. Snelling [1 male, UCRC]; Laikipia County, Mpala Research Centre, $0.29^{\circ} \mathrm{N} 36.90^{\circ} \mathrm{E}, 1680 \mathrm{~m}$, 1-9.x.1999, R. Snelling [1 male, UCRC].

REMARKS. Under the name of $C$. quinqueguttata, Motschulsky [1863] described females, and under the name $C$. sexguttata - males, from the same locality. Bouèek [1977], acting as First Reviser, synonymized $C$. quinqueguttata under C. sexguttata. In such situation a vice versa choice would be definitely more logical and proper both nomenclaturally and taxonomically. Unfortunately, Trjapitzin [1989: 146], not being aware of that nomenclatural action by Bouèek, synonymized $C$. sexguttata under $C$. quinqueguttata. We have no choice other than accepting $C$. sexguttata as the valid name of this species.

\section{Callipteroma testacea Motschulsky, 1863} Figs 7-8.

Calocerinella trifasciatus Girault, 1913 [correct spelling: trifaciata], synonymy by Noyes, 1978: 549; Leptomastix trifasciatipennis Girault, 1915, synonymy by Noyes, 1978: 549; Leptomastix penangi Girault, 1919, synonymy by Noyes, 1978: 549-550; Leptomastix geminus Girault, 1923 [correct spelling: gemina], synonymy by Noyes, 1978: 549, 551; Leptomastidea sayadriae Mani et Kaul, 1974, synonymy by Hayat, 1981: 17.

Motschulsky [Motschoulsky], 1863: 37-38; Girault, 1913: 47 (Calocerinella trifasciatus); Girault, 1915: 150 (Leptomastix trifasciatus), 152 (Leptomastix trifasciatipennis); Girault, 1919: 165 (Leptomastix penangi); Girault, 1923: 47 (Leptomastix geminus); Trjapitzin, 1965: 313-316 (Callipteroma testaceum); Mani \& Kaul, 1974: 70-72 (Leptomastidea sayadriae); Noyes, 1978: 549-551; Mani, 1989: 818; Noyes \& Hayat, 1994: 255-257; Dahms \& Gordh, 1997: 91-92; Japoshvili \& Noyes, 2005: 137; Hayat, 2006: 264265.

DISTRIBUTION. Saudi Arabia, Pakistan, India, Bangladesh, Sri Lanka, Malaysia, Indonesia, Papua New Guinea, Australia, Gambia, Nigeria, Namibia, Zimbabwe, Republic of South Africa, Madagascar.HOSTS. Birendracoccus saccharifolii (Green, 1908) (Pseudococcidae) on sugarcane in India [Noyes \& Hayat, 1994] and unidentified Pseudococcidae on Cocculus trilobus in Japan [Tachikawa, 1970].

TYPE MATERIAL EXAMINED. 1 male original syntype [ZMUM], collected on Mount Patannas, Sri Lanka, designated here as lectotype to avoid any confusion about the type specimens of this species and its identity, on a paper rectangle labeled: 1. [a small quadrate] "type"; 2. [a yellow quadrate] "Callipteroma testacea Motsch.”.

MATERIAL EXAMINED. INDONESIA: Komodo Island, sea level, palm savannah (Borassus), by sweeping Imperata cylindrica (Poaceae), 5.viii.1962, I. S. Darevsky [1 female, ZISP]. Padar 
Island, dry slopes of a gorge, by sweeping Imperata cylindrica, 13.viii.1962, I. S. Darevsky [1 male, ZISP]; PAPUA NEW GUINEA: Central Province: 15 km SE of Port Moresby, 1.i.1986, Eucalyptus grassland, G. Gordh [1 male, UCRC]; Ca. $30 \mathrm{~km} \mathrm{E} \mathrm{of} \mathrm{Port}$ Moresby (near Uariaraka), 28.xii.1985, Eucalyptus grassland, G. Gordh [1 male, UCRC]; AUSTRALIA: Northern Territory, $58 \mathrm{~km}$ SE of Adelaide River, 28.iii.1991, J. D. Pinto [1 female, UCRC] Queensland: Brisbane, Acacia Ridge: 27.ix.1980, E. Dahms, G. Gordh [2 females, UCRC]; Calam Rd., 31.viii.1980, G. Gordh, E. Dahms [1 male, UCRC]; $9.3 \mathrm{~km} \mathrm{~N}$ of Ellis Beach, $50 \mathrm{~m}$, on kangaroo grass, 30.iv.1990, J. M. Heraty [1 female, UCRC]; Gatton, 10-11.ix.1980, G. Gordh, E. Dahms [2 females, 1 male, UCRC].

REMARKS. On fig. 5 in Trjapitzin [1965: 315], female fore wing of $C$. testacea looks too long. That was due to an imperfection of the drawing apparatus used then.

ACKNOWLEDGEMENTS. The senior author thanks Natalia A. Florenskaya (Saint Petersburg, Russia) for the artistic drawings and Dr. Alexandr V. Antropov (ZMMU) for his friendly help. The junior author thanks Sharon A. Andreason (Department of Entomology, University of California at Riverside) for providing access to the colony of Gyranusoidea indica.

\section{References}

Ashmead W.H. 1900. On the genera of chalcid-flies belonging to subfamily Encyrtinae // Proceedings of the United States National Museum. Vol.22. No.1202. P.323-412.

Bouček Z. 1977. A faunistic review of the Yugoslavian Chalcidoidea (parasitic Hymenoptera) // Acta Entomologica Jugoslavica. Vol.3 (Supplement). P.1-145.

Dahms E.C., Gordh G. 1997. A review of the genera of Australian Encyrtidae (Hymenoptera: Chalcidoidea) described from Australia by A.A. Girault with a checklist of included species // Memoirs on Entomology, International. Vol.9. P.i-V +1-518.

Dalla Torre K.W. von. 1898. Catalogus Hymenopterorum hucusque descriptorum systematicus et synonymicus. V. Chalcididae et Proctotrupidae // Lipsiae. Vol.5. VIII + 598 pp.

Erdős J. 1964. 10 család: Encyrtidae - szivárványfürkészek // Fémfürkészek: Magyarország Állatvilága. XII Kötet. Hymenoptera II. 4. Füzet. Fémfürkészek - Chalcidoidea III. Budapest. 320 pp. (Fauna Hungariae. Vol.73.)

Gahan A.B., Fagan M.M. 1923. The type species of the genera of Chalcidoidea or chalcid-flies // Bulletin of the United States National Museum. Vol.124. P.I-III + 1-173.

García Mercet R. 1921. Fauna Ibérica. Himenópteros fam. encírtidos // Museo Nacional de Ciencias Naturales, Hipódramo, Madrid. VII-XI + 732 pp.

García Mercet R. 1924. Los géneros Leptomastidea, Callipteroma y Gyranusa // Boletín de la Real Sociedad Española de Historia Natural. Vol.24. P.252-260.

Girault A.A. 1913. A few new chalcidoid Hymenoptera from Queensland, Australia // Bulletin of the Wisconsin Natural History Society (new series). Vol.11 P.35-48.

Girault A.A. 1915. Australian Hymenoptera Chalcidoidea - VII. The family Encyrtidae with descriptions of new genera and species // Memoirs of the Queensland Museum. Vol.4. P.1-184.

Girault A.A. 1919. New chalcid parasites from Malaya // Journal of the Straits Branch of the Royal Asiatic Society. Vol.80. P.165-168.

Girault A.A. 1923. New Encyrtidae from Australia - I // Insecutor Inscitiae Menstruus. Vol.11. No.1-3. P.47-50.

Hayat M. 1974. First record of the encyrtid genus Callipteroma Motschulsky, 1863 (Hymenoptera: Chalcidoidea) from India // Journal of the Bombay Natural History Society. Vol.70. No.2. P.407-408.

Hayat M. 1981. Taxonomic notes on Indian Encyrtidae (Hym.: Chalcidoidea). II // Journal of Natural History. Vol.15. No.1. P.17-29.
Hayat M. 2006. Indian Encyrtidae (Hymenoptera: Chalcidoidea). [Keys to genera and species, and a catalogue, with 1591 figures] // Privately published, Aligarh, India. i-viii +496 pp.

Herthevtzian E.K. 1986. [Entsirtids (Encyrtidae) of Armenian SSR] // Fauna Armyanskoy SSR: [hymenopterous insects] Akademiya Nauk Armyanskoy SSR, Institut Zoologii, Erevan. 226 pp. [In Russian]

Hoffer A. 1975. Die Arten der Gattung Leptanusia De Santis, 1963 (Hym., Chalc., Encyrtidae) // Studia entomologica forestalia. Vol. 2. No.6. P.111-116.

Ishii T. 1928. The Encyrtinae of Japan. I // Bulletin of the Imperial Agricultural Experiment Station of Japan. Vol.3. No.2. P.79-160.

Japoshvili G., Noyes J.S. 2005. Checklist and new data on Encyrtidae of Transcaucasia and Turkey (Hymenoptera: Chalcidoidea) // Zoosystematica Rossica. Vol.14. No.1. P.135-145.

Kaul K., Agarwal M.M. 1986. Taxonomic studies on encyrtid parasitoids (Hymenoptera: Chalcidoidea) of India (with XVII plates) // Aligarh Muslim University Publication (Zoological Series) on Indian Insect Types. Vol.13. P.i-V + 1-89.

Krivokhatsky V.A., Mikhailov K.G. [Compilers] 2013. [Life adventures of Victor Ivanovich Motschulsky, by his own description]. Moscow - Saint Petersburg: KMK Scientific Press. 261 pp. [In Russian]

Mani M.S. 1989. The fauna of India and adjacent countries, Chalcidoidea (Hymenoptera. Part I). Agaontidae, Torymidae, Leucospidae, Chalcididae, Eurytomidae, Perilampidae, Eucharitidae, Cleonymidae, Miscogasteridae, Pteromalidae, Eupelmidae and Encyrtidae. Zoological Survey of India, Calcutta. xiv +1067 pp.

Mani M.S., Kaul B.K. in Mani M.S., Dubey O.P., Kaul B.K., Saraswat G.G. 1974. Descriptions of some new and new records of some known Chalcidoidea (Hymenoptera) from India // Memoirs of the School of Entomology, St. John's College, Agra. No.3. P.1-108.

Masi L. 1921. Descrizione del maschio di Eupelmella schizomyiae e di un nuovo Leptomastix della Cirenaica (Hymen. Chalcididae) // Annali del Museo Civico di Storia Naturale di Genova (Giacomo Doria). Vol.9. No.49. P.298-303.

Motschulsky V. de. 1859. Inesctes utiles et nuisibles // Études Entomologiques [Helsingfors]. Vol.8. P.169-174.

Motschulsky V. de. 1863. Essai d'un catalogue des insectes de l'Ile Ceylan (Suite) // Byulleten' Moskovskogo Obshchestva Ispytateley Prirody (Otdel Biologicheskiy) [Bulletin de la Société impériale des naturalistes de Moscou]. Vol.36. No.3. P.1-153.

Myartseva S.N. 1978. [Encyrtids of the genus Leptanusia De Santis, 1963 (Hymenoptera, Chalcidoidea) of the world fauna] // Entomologicheskoe Obozrenie. Vol.57. No.1. P.162-168 [in Russian].

Myartseva S.N. 1982. [New species of parasitic Hymenoptera (Chalcidoidea, Encyrtidae) from Central Asia and Afghanistan] // Izvestiya Akademii Nauk Turkmenskoy SSR (Seriya Biologicheskikh Nauk). No.6. P.39-46 [in Russian].

Myartseva S.N. 1984. [Parasitic Hymenoptera of the family Encyrtidae (Hymenoptera, Chalcidoidea) of Turkmenistan and adjacent Regions of Central Asia]. Ashkhabad: Ylym. 304 pp. [In Russian]

Myartseva S.N. 1986. [Encyrtids (Hymenoptera, Chalcidoidea, Encyrtidae) of deserts and semi-deserts of Central Asia (Fauna, ecology, biology, distribution, economic importance)] // Ashkhabad: Ylym. 304 pp. [in Russian].

Nikol'skaya M.N. 1952. [Chalcids of the fauna of the USSR (Chalcidoidea)] // Opredeliteli po faune SSSR, izdavaemye Zoologichesckim institutom Akademii Nauk SSSR [Keys to the Fauna of the USSR, published by the Zoological Institute of the Academy of Sciences of the USSR], Iss.44. Moscow - Leningrad: AN SSSR Publ. 574 pp. + table of contents on an unnumbered page. [In Russian]

Nikol'skaya M.N. 1963. The chalcid fauna of the USSR (Chalcidoidea) // Israel Program of Scientific Translations. Jerusalem. $593 \mathrm{pp}$

Noyes J.S. 1978. A revision of the encyrtid genus Callipteroma Motchulsky [sic] (Hymenoptera: Encyrtidae) // Australian Journal of Zoology. Vol.26. No.3. P.539-553. 
Noyes J.S. 1980. A review of the genera of Neotropical Encyrtidae (Hymenoptera: Chalcidoidea) // Bulletin of the British Museum (Natural History), Entomology series. Vol.41. No.3. P.107-253.

Noyes J.S., Hayat M. 1984. A review of the genera of Indo-Pacific Encyrtidae (Hymenoptera: Chalcidoidea) // Bulletin of the British Museum (Natural History), Entomology series. Vol.48. No.3. P.131-395.

Noyes J.S., Hayat M. 1994. Oriental mealybug parasitoids of the Anagyrini (Hymenoptera: Encyrtidae) with a world review of Encyrtidae used in classical biological control and an index of encyrtid parasitoids of mealybugs (Homoptera: Pseudococidae) // CAB International, Wallingford, Oxon, UK. i-viii + 554 pp.

Summerville W.A.T. 1928. Mealy bug attacking paspalum grass in the Cooray district // Queensland Agricultural Journal. Vol.3. No.3. P.201-209.

Tachikawa T. 1962. On Callipteroma kiushiuense Ishii (Hymenoptera: Encyrtidae) // Transactions of the Shikoku Entomological Society. Vol.7. No.3. P.79.

Tachikawa T. 1963. Revisional studies of the Encyrtidae of Japan (Hymenoptera: Chalcidoidea) // Memoirs of the Ehime University, Sect. VI (Agriculture). Vol.9. No.1. P.1-264.

Tachikawa T. 1970. A revised list of the hosts of encyrtid genera (Hymenoptera: Chalcidoidea) // Transactions of the Shikoku Entomological Society. Vol.10. No.3-4. P.84-99.

Triapitsyn S.V., Aguirre M.B., Logarzo G.A., Dal Molin A. 2014 Taxonomic notes on primary and secondary parasitoids (Hymenoptera: Encyrtidae and Signiphoridae) of Hypogeococcus spp. (Hemiptera: Pseudococcidae) in Argentina // Acta Zoológica Lilloana. Vol.58. No.2. P.171-186.

Trjapitzin V.A. 1961. [On the type of Diversinervus paradisicus (Motsch.) (Hymenoptera, Encyrtidae)] // Entomologicheskoe Obozrenie. Vol.40. No.3. P.669-672 [in Russian].

Trjapitzin V.A. 1965. Contribution to the knowledge of the encyrtid fauna of the Comodo and Padar Islands with a catalogue of the Indonesian species (Hymenoptera, Encyrtidae)//Treubia. Vol.26. Pt.4. P.309-327.
Trjapitzin V.A. 1968. [Problems connected with morphological evolution and classification of the fam. Encyrtidae (Hymenoptera, Chalcidoidea)] // Doklady na dvadtsatom ezhegodnom chtenii pamiati N.A. Kholodkovskogo [Paper read at the 20th annual N.A. Kholodkovskiy memorial lecture], 14th April 1967. Leningrad, Nauka, Leningrad Branch. P.44-62 [in Russian].

Trjapitzin V.A. 1971a. [Review of the genera of Palaearctic encyrtids (Hymenoptera, Encyrtidae)] // Trudy Vsesoyuznogo Entomologicheskogo Obshchestva [Horae Societatis Entomologicae Unionis Soveticae]. Vol.54. P.68-155 [in Russian].

Trjapitzin V.A. 1971b. [A new species of parasitic Hymenoptera of the genus Leptanusia De Santis, 1963 (Hymenoptera, Encyrtidae)] // Izvestia Akademii Nauk Turkmenskoy SSR [Series of biological sciences]. No.3. P.86-89 [in Russian].

Trjapitzin V.A. 1978. 7. [Fam. Encyrtidae - encyrtids] // Medvedev G.S. (chief ed.). [Keys to the insects of the European part of the USSR]. Volume III. Hymenoptera, Part 2 [Trjapitzin V.A. (ed.).] Leningrad: Nauka. P.236-328 [in Russian.]

Trjapitzin V.A. 1989. [Parasitic Hymenoptera of the fam. Encyrtidae of Palaearctics] // Leningrad: Nauka. 488 pp. [in Russian].

Trjapitzin V.A. 2008. Redescription of Charitopus cuprifrons (Motschulsky, 1863) from Sri Lanka, and a new name for the genus Sancarlosia Trjapitzin et Myartseva // Russian Entomological Journal. Vol.17. No.2. P.213-216.

Trjapitzin V.A. 2009. [Review of species of the genus Leptomastidea Mercet, 1916 (Hymenoptera, Encyrtidae) of the world, with description of a new species from Montenegro and with separation of a new genus from Turkmenia] // Entomologicheskoe Obozrenie. Vol.88. No.1. P.164-176 [in Russian].

Trjapitzin V.A., Ruíz-Cancino E., Coronado-Blanco J.M. 2008. Microterys nietneri (Motschulsky, 1859), parasitoide eficiente de Coccidae, especialmente en cítricos // Serie avispas parasíticas de plagas y otros insectos (Editorial Planea, Universidad Autónoma de Tamaulipas, Cd. Victoria, México). No.5. P.1-114. 